\title{
Evaluation of free-radical quenching properties of standard Ayurvedic formulation Vayasthapana Rasayana
}

\author{
Sourav Mukherjee, Nayana Pawar, Omkar Kulkarni, Bhagyashri Nagarkar², Shrikant Thopte², Akshay Bhujbal ${ }^{1}$ and \\ Pankaj Pawar $3^{3 *}$
}

\begin{abstract}
Background: Cellular damage induced by free-radicals like Reactive Oxygen and Nitrogen Species (ROS and RNS) has been implicated in several disorders and diseases, including ageing. Hence naturally occurring anti-oxidant rich-herbs play a vital role in combating these conditions. The present study was carried out to investigate the in vitro free-radical quenching capacity of a known Ayurvedic poly-herbal formulation called Vayasthapana Rasayana.

Methods: Methanol extracts of Vayasthapana Rasayana formulation (VRF) were studied for in vitro total antioxidant activity along with phenolic content and reducing power. In vitro assays like DPPH, FRAP, ABTS scavenging to evaluate radical quenching potential were performed.

Results: The formulation has shown $94 \%$ at $0.1 \mathrm{mg} / \mathrm{ml}$ DPPH free-radical scavenging activity as against $84 \%$ at 0.1 $\mathrm{mg} / \mathrm{ml}$ for standard ascorbic acid (IC 50 value $5.51 \mathrm{\mu g} / \mathrm{ml}$ for VRF and $39 \mu \mathrm{g} / \mathrm{ml}$ for standard). It has a significant higher ferric reducing potential also (OD 0.87 at $700 \mathrm{~nm} \& 0.21$ at $0.1 \mathrm{mg} / \mathrm{ml}$ for VRF and standard, respectively). The total phenolic content (gallic acid equivalent) of the VRF is $8.3 \mathrm{mg}$ per $\mathrm{g}$ of dry mass. Total antioxidant capacity of the formulation, estimated by FRAP was $1150 \pm 5 \mu \mathrm{M} \mathrm{Fe}(\mathrm{II}) / \mathrm{g}$ dry mass. ABTS radical scavenging activity of VRF was $69.55 \pm 0.21 \%$ at $100 \mu \mathrm{g} / \mathrm{ml}$ concentration with a $\mathrm{IC}_{50}$ value of $69.87 \mu \mathrm{g} / \mathrm{ml}$ as against $9 \%$ and $95 \%$ by ascorbic acid and Trolox (at $70.452 \mu \mathrm{g} / \mathrm{ml}$ and $0.250 \mu \mathrm{g} / \mathrm{ml}$ concentrations, respectively).

Conclusion: In Indian traditional Ayurvedic system, use of VRF is in regular practice for mainly combating agerelated disorders and diseases as many of the components of the Rasayana are known for their free-radical scavenging activity. This study has validated the potential use of VRF as an anti-oxidant to fight age-related problems.
\end{abstract}

\section{Background}

In 2006, global aged population ( $\geq 60$ years) numbered 700 million, and it is speculated that by 2050 , this number would rise up to 2 billion. Worldwide the population of older individuals is growing at a rate of $2.6 \%$ per year, as against the population as a whole (1.1\% annually). India stands second in possessing maximum aged population in the world [1]. Besides, deterioration of quality of life due to untimely ageing in the world population needs to be addressed and a suitable solution, either in the

\footnotetext{
* Correspondence: pnkjpawar@yahoo.com

${ }^{3}$ Interactive Research School for Health Affairs, Bharati Vidyapeeth University,

Pune-Satara Road, Pune - 411 043, Maharashtra, India

Full list of author information is available at the end of the article
}

form of medication or dietary supplement needs to be explored. At the same time, existing traditional antiageing formulations also need to be validated using modern scientific technology and proper explanation.

Reactive Oxygen Species (ROS) and Reactive Nitrogen Species (RNS) including peroxides, super-oxides, hydroxyl radicals and nitrous oxide, generated in the living organisms by cellular metabolism, are known to play a vital role in oxidative cellular damage. Oxidative stress, resulting from these free-radicals plays an important role in manifesting various disorders, including ageing and diseases like cancer, CVD, Parkinson's and in living beings $[2,3]$. Recent investigations have shown that the antioxidant properties of plants could be correlated with

\section{Biomed Central}


oxidative stress defense, different human diseases and aging process [4]. ROS can easily initiate lipid peroxidation of the membrane lipids, causing damage to the cell membrane composed of phospholipids and lipoproteins by propagating a chain reaction cycle [5]. Thus, antioxidant defense systems have coevolved with aerobic metabolism to counteract oxidative damage from ROS. Also in this regard, total phenol content has received the greatest attention due to the fact that there is a direct relation between total phenol content of the plant with its free-radical scavenging potential [6].

Indian traditional Ayurved system has very specialized therapies for both timely and untimely ageing. According to Ayurved, ageing (Jara) is as natural as sleep, hunger, or any other instincts. It is described as a natural and inevitable process as well as natural disease [7]. Ageing is characterized by deterioration of natural physical and mental strengths and capabilities. A variety of drugs, selected from plants, minerals and of animal origin, classified under the name Rasayana, are in regular use of all Ayurvedic practitioners for slow down or reverting back timely as well as untimely ageing. These drugs may be having specific actions on respiratory system, cognition etc. or non-specific actions for overall age-related changes.

Rasayana therapy is one of the major methods of preservation of health and delaying the process of ageing as described in Ayurvedic system of medicine. Good health, according to Ayurved as well as modern medicinal systems, means more than being physically healthy. It involves maintenance of subtle functions of the body like cognition, intellect, strength and immunity etc. as observed from the definition of Rasayana Tantra (science of rejuvenation and restoration) by Sushuruta (1500 BC) [8]:

Rasayana tantra nama vayasthapanaayurmedhabalakaaram rogaapaharanasamartha cha. Su. Su. 1:7.

This means Rasayana has mainly got five different actions; (i) vayasthapana delaying the process of ageing, (ii) aayuskara i.e. increase in the life span (iii) balakara i.e. having anabolic properties to strengthen the body, (iv) medha balakara i.e. improvement of cognitive ability, (iv) roga-apaharana i.e. gaining immunity and curing from diseases.

The ancient text of Ayurveda 'Charaka Samhita' (1500 $\mathrm{BC}$ ) explains the component of a standard formulation used for retarding the untimely ageing process, called Vayasthapana Rasayana formulation (VRF). This formulation consists of plants, namely Asparagus racemosus (Shatavari), Boerhaavia diffusa (Punarnava), Clitoria ternatea (Gokarna), Phyllanthus emblica (Amla),
Terminalia chebula (Hirda), Centella asiatica (Mandookparni) and Tinospora cordifolia (Gulvel) [8].

In the present study, in vitro free-radical scavenging activities of VRF, as a probable basis of combating ageing and age-related disorders, were evaluated.

\section{Methods}

\section{Chemicals}

All chemicals used for assays were of analytical grade. 2,2-diphenyl-1-picrylhydrazyl (DPPH), ABTS (2, 2'azino-bis (3-ethylbenzthiazoline-6-sulphonic acid), TPTZ (2, 4, 6-tripyridyl-s-triazine), Trolox (6-hydroxy2,5,7,8-tetramethylchroman-2-carboxylic acid) and gallic acid were procured from Sigma-Aldrich, USA. Potassium persulfate $\left(\mathrm{K}_{2} \mathrm{~S}_{2} \mathrm{O}_{8}\right)$, sodium nitroprusside (SNP), Ferric chloride $\left(\mathrm{FeCl}_{3} \cdot 6 \mathrm{H}_{2} \mathrm{O}\right)$, Hydrochloric acid $(\mathrm{HCl})$, potassium hexacyanoferrate $\left(\mathrm{K}_{2} \mathrm{Fe}(\mathrm{CN})_{6}\right)$, Ferrous sulphate $\left(\mathrm{FeSO}_{4}\right)$ and Tricarboxylic acid were procured from Qualigens Pvt. Ltd, Mumbai, India.

\section{Plant materials}

Fine powders of Phyllanthus emblica (Awla) and Boerhaavia diffusa (Punarnava) were procured from Green pharmacy, Pune. Mature stem of Tinospora cordifolia (Gulvel), unripe fruits of Terminalia chebula (Hirda), entire plant of Clitoria ternatea (Gokarna), leaves of Centella asiatica (Mandookparni) and mature roots of Asparagus racemossus (Shatavari) were collected from wild sources of Western Ghats, dried in shade at $30^{\circ} \mathrm{C}$ and ground into fine powder.

\section{Formulation (VRF) preparation}

Standard Vayasthapana Rasayana formulation (VRF) was prepared by mixing the fine powder of all plants in equal proportion [8].

\section{Extraction}

Methanolic extracts of VRF were prepared by mixing $10 \%$ powder in solvent by constant agitation on a shaker $\left(150 \mathrm{rpm}, 30^{\circ} \mathrm{C}, 24 \mathrm{~h}\right)$ [9]. Extracts were filtered through Whatman filter paper (No. 1) and the filtrate was centrifuged $\left(10000 \mathrm{rpm}, 10^{\circ} \mathrm{C}, 10 \mathrm{~min}\right)$ to obtain a clear supernatant. Its yield was determined and $10 \mathrm{mg} / \mathrm{ml}$ stock solution prepared, which was stored in amber coloured bottles at $4^{\circ} \mathrm{C}$ till further studies.

\section{Standards}

Ascorbic acid was used as a standard for DPPH-free radical scavenging assay and for reducing power assay. Trolox and ascorbic acid served as two standards for ABTS scavenging assay and ferrus sulphate for FRAP assay. For total phenol content calculation, gallic acid was used as the standard. 


\section{In vitro anti-oxidant assays}

\section{Total anti-oxidant capacity (ABTS assay)}

The method of Re et al. [10] was adopted for the determination of ABTS activity of the formulation (VRF). This assay is based on decolorization that occurs when the radical cation $\mathrm{ABTS}^{+}$is reduced to $\operatorname{ABTS}^{\prime}\left(2,2^{\prime}-\right.$ azino-bis (3-ethylbenzthiazoline-6-sulphonic acid). In brief, the radical was generated by reaction of a $7 \mathrm{mM}$ solution of ABTS in water with $2.45 \mathrm{mM}$ potassium persulphate $\left(\mathrm{K}_{2} \mathrm{O}_{8} \mathrm{~S}_{2}\right)(1: 1)$. The mixture was held in darkness at $27^{\circ} \mathrm{C}$ for $16 \mathrm{~h}$ (time needed to obtain stable absorbance at $734 \mathrm{~nm}$ ). After incubation, the radical solution was further diluted with water $(1 \mathrm{ml}$ of ABTS reagent $+27 \mathrm{ml} \mathrm{DW}$ ) until the initial absorbance value of $0.7 \pm 0.005$ at $734 \mathrm{~nm}$ was reached.

For the assay of test samples $980 \mu \mathrm{l}$ of $\mathrm{ABTS}^{.+}$reagent was mixed with $20 \mu \mathrm{l}$ of the sample or standard. Absorbance was taken after $6 \mathrm{~min}$ at $734 \mathrm{~nm}$. $\Delta$ O.D. was calculated between initial $(0 \mathrm{~min}$. $)$ and $6^{\text {th }} \mathrm{min}$. reading. As a standard, ascorbic acid $(8.8 \mu \mathrm{g} / \mathrm{ml}$ to $88.0 \mu \mathrm{g} / \mathrm{ml})$ and Trolox $(0.062 \mu \mathrm{g} / \mathrm{ml}$ to $0.312 \mu \mathrm{g} / \mathrm{ml})$ were used.

The percentage of scavenging inhibition capacity of ABTS $^{++}$of the extract was calculated using the following equation and compared with ascorbic acid and Trolox.

$$
\begin{aligned}
\text { \%inhibition }= & {\left[\left(\mathrm{Abs}_{\text {control }}-\mathrm{Abs}_{\text {sample }}\right)\right] / } \\
& \left.\left(\mathrm{Abs}_{\mathrm{control}}\right)\right] \times 100
\end{aligned}
$$

\section{Total antioxidant activity (FRAP assay)}

A slightly modified method of Benzie and Strain [11] was adopted for the FRAP assay. The stock solutions included $300 \mathrm{mM}$ acetate buffer $\left(3.1 \mathrm{~g} \mathrm{CH}_{3} \mathrm{COONa}\right.$ and $16 \mathrm{ml} \mathrm{CH} \mathrm{CHOH}_{3} \mathrm{OH}$ 3.6), $10 \mathrm{mM}$ TPTZ (2, 4, 6-tripyridyl-s-triazine) solution in $40 \mathrm{mM} \mathrm{HCl}$, and $20 \mathrm{mM}$ $\mathrm{FeCl}_{3} \cdot 6 \mathrm{H}_{2} \mathrm{O}$ solution. This assay involved (i) preparation of fresh FRAP solution by mixing $25 \mathrm{ml}$ acetate buffer, $2.5 \mathrm{ml} \mathrm{TPTZ}$, and $2.5 \mathrm{ml} \mathrm{FeCl}_{3} \cdot 6 \mathrm{H}_{2} \mathrm{O}$, (ii) raising temperature of the solution to $37^{\circ} \mathrm{C}$, (iii) allowing plant extracts $(150 \mu \mathrm{L})$ allowed to react with $2850 \mu \mathrm{l}$ of the FRAP solution for $30 \mathrm{~min}$ in the dark and (iv) taking readings of the coloured product (ferrous tripyridyl triazine complex) at $593 \mathrm{~nm}$. The standard curve was linear between 200 and $1000 \mu \mathrm{M} \mathrm{FeSO}_{4}$. Results are expressed in $\mu \mathrm{M} \mathrm{Fe}(\mathrm{II}) / \mathrm{g}$ dry mass.

\section{DPPH free radical scavenging assay}

Complementarities of the antioxidant capacity of the formulation was confirmed by the DPPH scavenging assay according to Brand-Williams et al. [12] with slight modification. Different concentrations ( 0.01 to $0.1 \mathrm{mg}$ / $\mathrm{ml}$ ) of the extracts and ascorbic acid (standard) were thoroughly mixed with $5 \mathrm{ml}$ of methanolic DPPH solution $(33 \mathrm{mg} / \mathrm{L})$ in test-tubes and the resulting solution was kept standing for 10 minutes at $37^{\circ} \mathrm{C}$ before the optical density (OD) was measured at $517 \mathrm{~nm}$. The measurement was repeated with three sets and an average of the reading was considered. The percentage radical scavenging activity was calculated from the following formula:

$$
\% \text { scavenging }[\mathrm{DPPH}]=[(\mathrm{A} 0-\mathrm{A} 1) / \mathrm{A} 0] \times 100
$$

Where $A_{0}$ was the absorbance of the control and $A_{1}$ was the absorbance in the presence of the samples.

$\mathrm{IC}_{50}$ value was determined from the graph obtained using standard ascorbic acid by using the " $y=m x+c$ " formula from the slope of the graph.

\section{Reducing power assay}

The $\mathrm{Fe}^{3+}$-reducing power of the extract was determined by a method described by Hazra et al., [13] with slight modification. The assay involved (i) mixing different concentrations $(0.01$ to $0.1 \mathrm{mg} / \mathrm{ml})$ of the extracts in phosphate buffer $(0.2 \mathrm{M}, \mathrm{pH} 6.6)$ with potassium hexacyanoferrate $(0.1 \%)$, (ii) incubation at $50^{\circ} \mathrm{C}$ for $20 \mathrm{~min}$, (iii) arresting the reaction by addition of $10 \%$ tricarboxylic acid (TCA) and distilled water $(2.5 \mathrm{ml})$, (iv) adding $\mathrm{FeCl}_{3}$ solution $(0.01 \%)$ to the upper portion of the reaction mixture, (v) leaving the reaction mixture for $10 \mathrm{~min}$ at room temperature for colour development and (vi) measuring absorbance at $700 \mathrm{~nm}$. All tests were performed in triplicate. Ascorbic acid was used as a positive control. A higher absorbance of the reaction mixture indicated greater reducing power.

\section{Determination of total phenolic content}

The amount of total phenolics present in VRF extract was determined using Folin-Ciocalteu (FC) reagent by Hazra et al. [14]. A gallic acid standard curve $\left(\mathrm{R}^{2}=0.9\right)$ was used to measure the phenolic content.

\section{Results and Discussion}

Total anti-oxidant capacity (ABTS assay) and DPPH free radical scavenging

The VRF was efficient in scavenging the radical cation $\mathrm{ABTS}^{+}$which was reduced to ABTS'. Percentage radical scavenging of the formulation was $69.55 \pm 0.21 \%$ at a of concentration $100 \mu \mathrm{g} / \mathrm{ml}$ (Figure 1), where that of ascorbic acid and Trolox was $9 \pm 0.5 \%$ and $95 \pm 0.5 \%$ at $70.452 \mu \mathrm{g} / \mathrm{ml}$ and $0.250 \mu \mathrm{g} / \mathrm{ml}$ concentration respectively. The $\mathrm{IC}_{50}$ value of the formulation was calculated using " $\mathrm{y}=\mathrm{mx}+\mathrm{c}$ " formula, which was $69.87 \mu \mathrm{g} / \mathrm{ml}$ and that for the standard ascorbic acid and Trolox was $0.546 \mu \mathrm{g} / \mathrm{ml}$ and $0.025 \mu \mathrm{g} / \mathrm{ml}$ respectively. VRF was also found to be a potential DPPH-free radical scavenger, since concentration of $0.1 \mathrm{mg} / \mathrm{ml}$, the activity was $94 \pm 0.5 \%$. From the graph, the $\mathrm{IC}_{50}$ value of the formulation was calculated as $5.51 \mu \mathrm{g} / \mathrm{ml}$. The percentage scavenging activity of standard (ascorbic acid) was 


\section{ABTS scavenging by VRF}

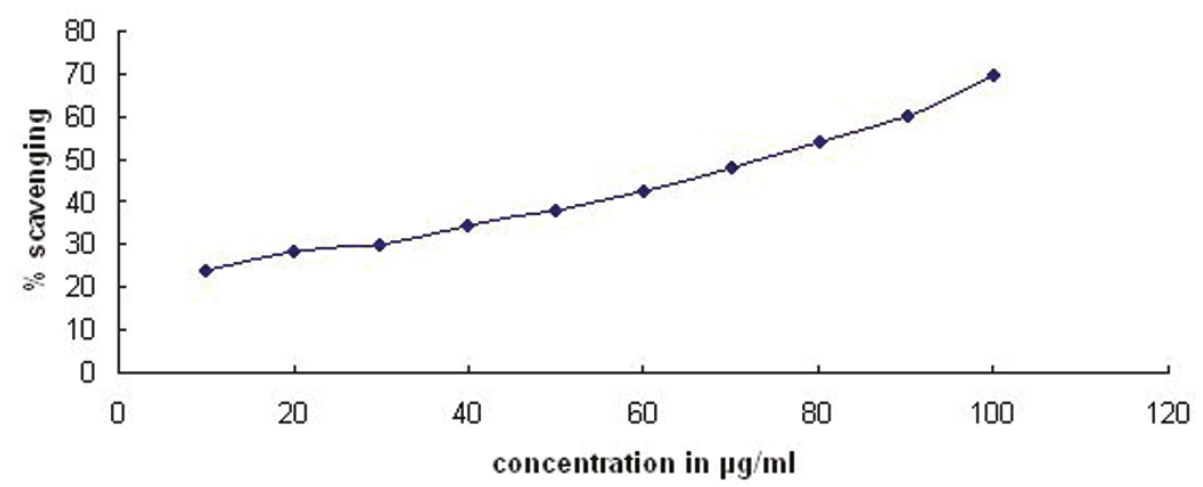

Figure 1 ABTS free-radical scavenging activity of VRF

only $84 \%$ at $0.1 \mathrm{mg} / \mathrm{ml}$ and $\mathrm{IC}_{50}$ value was $39 \mu \mathrm{g} / \mathrm{ml}$ (Figure 2).

\section{Interrelation between DPPH radical and ABTS radical scavenging}

Plants with antioxidant activities have been reported to possess free radical scavenging activity [14]. The DPPH scavenging activity in this study indicated that the formulation was potent anti-oxidant. This also suggested that the formulation contained compounds that are capable of donating hydrogen to a free radical in order to remove odd electron, which is responsible for the radical's reactivity [14]. In the present study, standard VRF has shown $93 \%$ free radical scavenging activity at a concentration $0.1 \mathrm{mg} / \mathrm{ml}$. It is known that many of these components of Rasayana are known as free-radical scavengers [15]. Similarly, Phyllanthus emblica and Terminalia chebula individually have also shown significantly high DPPH-free-radical scavenging activity $(85 \%$ and
$93 \%$, respectively) at $0.1 \mathrm{mg} / \mathrm{ml}$ concentration (data not shown). The free-radical scavenging activity of VRF was more than standard ascorbic acid $(84 \%$ at $0.1 \mathrm{mg} / \mathrm{ml}$ concentration). Also the $\mathrm{IC}_{50}$ values of VRF and standard ascorbic acid showed a huge forbidden gap (5.51 $\mu \mathrm{g} / \mathrm{ml}$ for VRF and $39 \mu \mathrm{g} / \mathrm{ml}$ for standard), clearly indicating that the formulation is more potent in scavenging free radicals in vitro. The ability of this formulation to scavenge DPPH could also reflect its ability to inhibit the formation of $\mathrm{ABTS}^{+}$. The scavenging activity of $\mathrm{ABTS}^{+}$radical by the formulation was found $69.55 \pm$ $0.21 \%$ at $100 \mu \mathrm{g} / \mathrm{ml}$. For DPPH free radical scavenging and ABTS radical scavenging the $\mathrm{IC}_{50}$ values were 5.51 $\mu \mathrm{g} / \mathrm{ml}$ and $69.87 \mu \mathrm{g} / \mathrm{ml}$ for VRF. This difference in the values may be due to the presence of some potent molecule (s) in the formulation which is more capable of quenching DPPH radical than ABTS radical.

It is known that proton radical scavenging is an important attribute of antioxidants. ABTS, a protonated

\section{Comparison of DPPH radical scavenging by VSRF \& ascorbic acid}

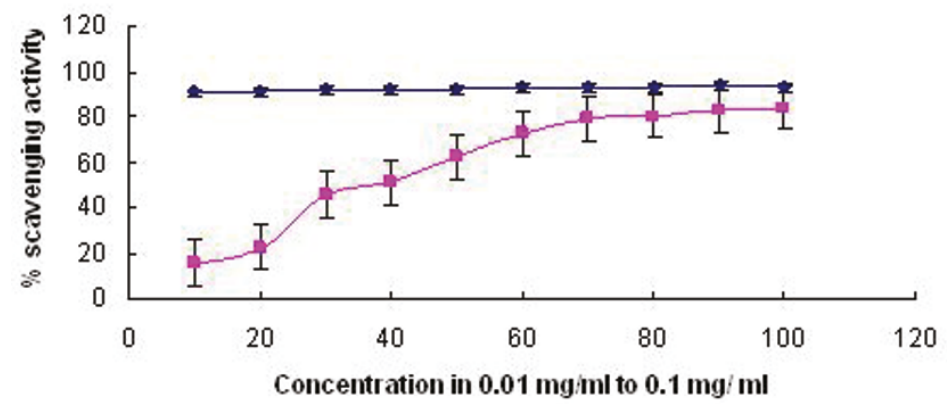

Figure 2 Comparison of DPPH free-radical scavenging activity of VRF and ascorbic acid.

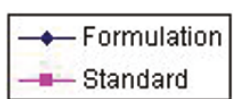


radical, has characteristic absorbance maxima at 734 $\mathrm{nm}$, which decreases with the scavenging of proton radicals $[16,17]$. The 2,2'-azinobis-3-ethylbenzothiazoline6-sulfonic acid (ABTS) activity of the formulation were comparable to standard ascorbic acid and Trolox. This implies that the plant extract may be useful for treating radical-related pathological damage, especially at higher concentration [14]. Since the $\mathrm{IC}_{50}$ value of Trolox, which is known to be a potent antioxidant is $0.11 \mu \mathrm{g} /$ $\mathrm{ml}$, which is significantly low, implies that a very less amount of this antioxidant would give a remarkably high effect in fighting oxidative damage. However, VRF has shown $\mathrm{IC}_{50}$ value $69.87 \mu \mathrm{g} / \mathrm{ml}$, which necessarily indicates that rather a higher dose is required to achieve a desirable effect."

The scavenging of the DPPH radical by the extracts was found to be higher than that of $\mathrm{ABTS}^{+}$radical. Various factors like (i) stereo-selectivity of the radicals, (ii) solubility of the extract in different testing systems, (iii) polarity of the solvent, (iv) functional groups present in the bioactive compounds, have been reported to affect the capacity of extracts to react and quench different radicals [17]. Our results demonstrated that the formulation under investigation was a potent DPPH-radical and $\mathrm{ABTS}^{+}$radical scavenger.

\section{Determination of total phenolic content and FRAP assay}

The total phenol content (gallic acid equivalent) of the VRF is $8.3 \mathrm{mg}$ per $\mathrm{g}$ of dry mass. It is known that total phenol content is responsible for the free-radical scavenging activities in many plants $[6,17]$. Total anti-oxidant potential was determined by FRAP and reducing ability of the extracts was $1150 \pm 5 \mu \mathrm{M} \mathrm{Fe}(\mathrm{II}) / \mathrm{g}$ dry mass.

The antioxidant potential of formulations was estimated from their ability to reduce TPRZ-Fe (III) complex to TPTZ-Fe (II). Antioxidant activities are known to increase directly proportional to the poly-phenol content. This activity is believed to be mainly due to their redox properties $[17,18]$, which plays an important role in (a) adsorbing and neutralizing free radicals, (b) quenching singlet and triplet oxygen, and (c) decomposing peroxides [17]. Also according to recent reports, a highly positive relationship between total phenols and antioxidant activity appears to be the trend in many plant species [17]. Our result also shows that the ABTS radical scavenging and $\mathrm{DPPH}$ free-radical scavenging activities are significantly high, which may be due to the presence of phenolic compounds in the VRF.

\section{Reducing power assay}

In the reducing power assay, the presence of antioxidants in the sample would result in the reduction of $\mathrm{Fe} 3+$ to $\mathrm{Fe} 2+$ by donating an electron. The amount of Fe2+ complex can then be monitored by measuring the formation of Perl's blue at $700 \mathrm{~nm}$. Increasing absorbance indicates an increase in reductive ability [14]. Since reducing power of a compound serves as a significant indicator of its antioxidant activity [19], VRF was assayed for the reducing power activity. It has shown in vitro ferric reducing potential. The OD at $700 \mathrm{~nm}$ increased in a dose dependent manner from 0.33 at $0.01 \mathrm{mg} / \mathrm{ml}$ to 0.87 at $0.1 \mathrm{mg} / \mathrm{ml}$. For this assay also, ascorbic acid was used as a standard. The OD at $700 \mathrm{~nm}$ ranged from 0.03 at $0.01 \mathrm{mg} / \mathrm{ml}$ and 0.21 at $0.1 \mathrm{mg} / \mathrm{ml}$ (Figure 3).

According to Indian Ayurvedic system, ageing may be timely or untimely. Timely ageing, as mentioned by Indian sacred texts, are considered as a natural phenomenon in all living organisms. On the contrary, untimely ageing may be due to faulty food habits, sedentary lifestyle or stress. Faulty food habits lead to higher degree of accumulation of free radicals in the body. The freeradical theory of ageing emphasizes more on the

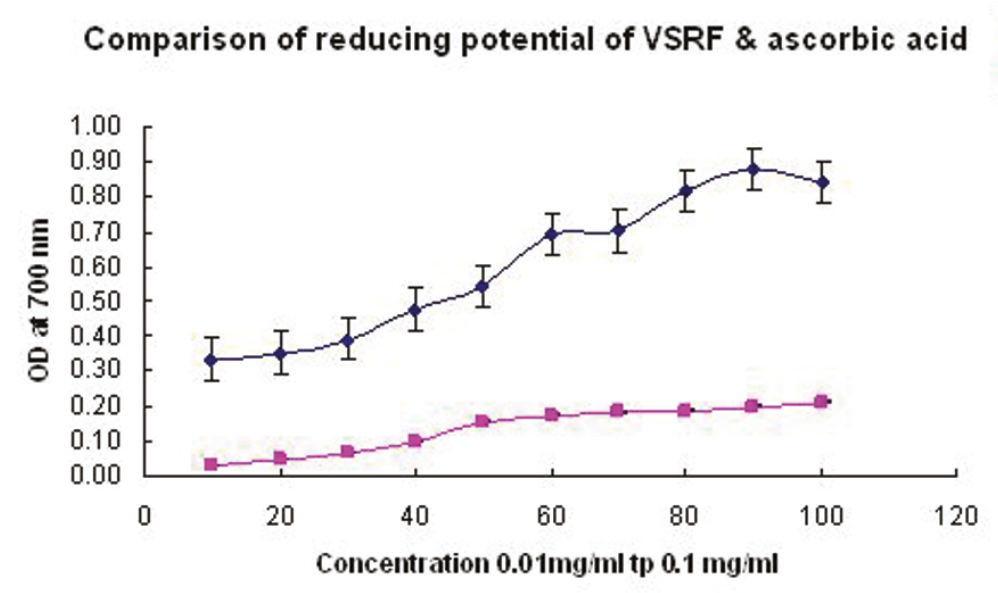

Figure 3 Comparison of reducing potential of VRF and standard ascorbic acid 
oxidative stress resulted from cellular metabolism and eventual generation of ROS or RNS [20]. Oxidative stress is also related to apoptosis in unicellular yeasts. It has been demonstrated in yeast, nematodes, flies and primates that mitochondrial ROS production causes cellular damage, resulting into overall decline in cellular functioning, eventually leading to ageing [21].

The ROS and RNS are common free radicals known to damage lipids, proteins, enzymes, and DNA [22,23]. Damages caused by free radicals (hydroxyl radicals, super-oxide anions, hydrogen peroxide, and nitric oxides) lead to cell or tissue injury and a wide range of degenerative diseases, including asthma, ulcer, cancer, Parkinson's [19]. According to free radical theory, as a result of accumulation of oxidatively damaged macromolecules and consequently cells or tissues due to aerobic metabolism to which individuals are continuously exposed, ageing is initiated in human beings [20]. Thus, anti-oxidant defense may be one of the major mechanisms to combat ageing and age-related problems.

\section{Conclusion}

This study affirms the in vitro antioxidant potential of crude methanolic extract of the standard Ayurvedic formulation, with results comparable or significantly higher to those of the standard compounds such as ascorbic acid and Trolox. Further studies are needed to clarify the in vivo potential of the formulation in the management of various age-related human diseases resulting from oxidative stress.

\section{Acknowledgements}

The authors are thankful to Bharati Vidyapeeth University for supporting this work, Prof. S. P. Mahadik for his constant support and valuable discussions during the progress of this work and Prof. P K Ranjekar and Dr. R M Kothari for critically going through the manuscript.

\section{Author details}

${ }^{1}$ Modern College for Arts, Science and Commerce, Shivajinagar, Pune - 411 005, Maharashtra, India. ${ }^{2}$ Rajiv Gandhi Institute for IT and Biotechnology, Bharati Vidyapeeth University, Pune-Satara Road, Pune - 411 046, Maharashtra, India. ${ }^{3}$ Interactive Research School for Health Affairs, Bharati Vidyapeeth University, Pune-Satara Road, Pune - 411 043, Maharashtra, India.

\section{Authors' contributions}

SM: Prepared the extract, carried out the assays and drafted the manuscript. NMP, BN, ST and AB: Carried out the assays. OPK: Generated the concept and gave Ayurvedic inputs. PKP: coordinated the study. All authors read and approved the final manuscript.

\section{Competing interests}

The authors declare that they have no competing interests.

Received: 9 July 2010 Accepted: 12 May 2011 Published: 12 May 2011
3. Dugasani S, Pichika MR, Nadarajah VD, Balijapalli MK, Tandra S, Korlakunta JN: Comparative anti-oxidant and anti-inflammatory effects of [6]-gingerol, [8]-gingerol, [10]-gingerol and [6]-shagaol. J Ethnopharmacol 2009.

4. Ara N, Nur $\mathrm{H}$ : In vitro antioxidant activity of methanolic leaves and flowers extracts of Lippia alba. Res J Medicine Med SC 2009, 4:107-110.

5. Braca A, Sortino C, Politi M, Morelli I, Mendez J: Antioxidant activity of flavonoids from Licania licaniaeflora. J Ethnopharmacol 2002, 79:379-381.

6. Pourmorad F, Hosseinimehr SJ, Shahabimajd N: Antioxidant activity, phenol and flavonoid contents of some selected Iranian medicinal plants. African J Biotech 2006, 5(11):1142-1145.

7. Tiwari BG, Upadhyay BN: Concept of ageing in Ayurveda. Ind J Trad Knowl 2009, 8:396-399.

8. Acharya JT, (Edt.): Carakasamhita by Agnivesa. 5 edition. Chaukhamba Sanskrit Sansthan, Varanasi, India; 2005.

9. Parekh J, Chanda SV: In vitro antimicrobial activity and phytochemical analysis of some Indian medicinal plants. Turk J Biol 2007, 31:53-58.

10. Re R, Pellegrini N, Proteggente A, Pannala A, Yang M, Rice-Evans C: Antioxidant activity: applying an improved ABTS radical cation decolorization assay. Free Rad Biol Med 1999, 26:1231-1237.

11. Benzie IFF, Strain JJ: The ferric reducing ability of plasma (FRAP) as a measure of "antioxidant power": the FRAP assay. Analyt Biochem 1996, 239:70-76.

12. Brand-Williams W, Cuvelier M, Berset C: Use of a free radical method to evaluate antioxidant activity. Lebensm Wiss Technol 1995, 28:25-30.

13. Hazra B, Biswas S, Mandal N: Antioxidant and free radical scavenging activity of Spondias pinnata. BMC Complement Altern Med 2008, 8:63.

14. Olayinka AA, Anthony IO: Preliminary phytochemical screening and In vitro antioxidant activities of the aqueous extract of Helichrysum longifolium DC. BMC Complement Altern Med 2010, 10:21.

15. Kapoor VK, Dureja J, Chadha R: Herbals in the control of ageing. Drug discovery today 2009, 14:992-998.

16. Mathew S, Abraham TE: In vitro antioxidant activity and scavenging effects of Cinnamomum verum leaf extract assayed by different methodologies. Food Chem Toxicol 2006, 44:198-206.

17. Adedapo AA, Jimoh FO, Afolayan AJ, Masika PJ: Antioxidant activities and phenolic contents of the methanol extracts of the stems of Acokanthera oppositifolia and Adenia gummifera. BMC Complement Altern Med 2008, 8:54-60.

18. Zheng W, Wang SY: Antioxidant activity and phenolic compounds in selected herbs. J Agricult Food Chem 2001, 49:5165-5170.

19. Bhaumik UK, Kumar AD, Selvan VT, Saha P, Gupta M, Mazumder UK: Antioxidant and free radical scavenging property of methanol extract of Blumea lanceolaria leaf in different in vitro models. Pharmacologyonline 2008, 2:74-89.

20. Harman D: Aging: A theory based on free radical and radiation chemistry. J Gerontol 1965, 11:298-300.

21. Daniel J: Sir-dependent down-regulation of various ageing processes. Mol Gen Genomics 2005, 274:539-547.

22. Duan XJ, Zhang WW, Li XM, Wang BG: Evaluation of antioxidant property of extract and fractions obtained from a red alga, Polysiphonia urceolata. Food Chem 2006, 95:37-43.

23. Mosquera OM, Correa YM, Buitrago DC, Niño J: Antioxidant activity of twenty five plants from Colombian biodiversity. Mem Inst Oswaldo Cruz Rio de Janeiro 2007, 102:631-634.

Pre-publication history

The pre-publication history for this paper can be accessed here: http://www.biomedcentral.com/1472-6882/11/38/prepub

doi:10.1186/1472-6882-11-38

Cite this article as: Mukherjee et al:: Evaluation of free-radical quenching properties of standard Ayurvedic formulation Vayasthapana Rasayana. BMC Complementary and Alternative Medicine 2011 11:38.

\section{References}

1. One word a million stories Development. [http://www.developments.org. uk/articles/india-facing-an-ageing-population].

2. Halliwell B: Anti-oxidants and human diseases: a general introduction. Nutri Rev 1997, 55:S44-S55. 